\title{
ENERGY EFFICIENT HOUSE WALL SYSTEM FOR ARID AND MODERATE CLIMATIC REGIONS
}

\author{
Fayez G. Aldawi ${ }^{1,2}$, Firoz Alam $^{2}$ and Hazim Moria ${ }^{1,2}$ \\ 1 Department of Mechanical Engineering, Yanbu Industrial College, Kingdom of Saudi Arabia \\ E-mail: faldawi@yic.edu.sa \\ 2 School of Aerospace, Mechanical and Manufacturing Engineering, RMIT University, Melbourne, Australia
}

\begin{abstract}
At present, a large percentage of fossil fuel energy is consumed by the residential households globally for ongoing heating and cooling. With currently used house wall envelope, it is difficult to achieve higher energy efficiency as it has reached the limit. Therefore, the primary objective of this study is to study a new house wall envelope and its thermal energy performance for ongoing heating and cooling in two climate (arid and moderate) conditions. The study was undertaken using computer simulation. The results indicate that new house wall envelope made of new materials and modular systems provides better thermal performance and significant energy savings compared to the widely used brick veneer house wall envelope. The findings also show that the percentage of energy savings of new house wall envelope for the arid climate is much higher than that of the moderate climate.
\end{abstract}

Keywords: House Thermal Performance, Arid Climate; Moderate Climate, Middle Eastern Residential Building, Building Materials, Energy Efficiency, Star Energy Rating

\section{INTRODUCTION}

The rapid growth of the population worldwide necessitates the construction of residential dwellings for human inhabitants in almost every corner of the world especially in the continents of Asia and Africa. The urbanization process makes many cities' population to increase multi-folds. This citypopulation expansion dramatically increases the demand for new buildings and houses along with huge energy needs. In developed countries, especially in Australia, the demand for residential houses and buildings has rapidly increased due to the increase in population numbers recently. A similar energy needs have also been reported for developing nations (e.g., Middle East, Far East, North
East, South East, and South Asia). A significant percentage of the total energy consumption and greenhouse gas emission is coming from building construction and dwelling. Globally, buildings account for about $20-30 \%$ of primary energy use and emission. Among the residential sector ongoing energy consumption, approximately $40 \%$ energy is used for heating and cooling only. Figure 1a indicates a sector wise energy consumption of a typical residential house in Australia However, this consumption will increase further as the floor space of the modern residential houses is progressively expanding [1-4]. The huge energy consumption in residential housing sectors have led many researchers to focus on energy 
conservation by improving ways of house construction using various materials and methods for varied climatic zones. In addition to huge energy consumption for heating and cooling, a significant percentage of energy is utilised for household hot water system $(-30 \%)$. The trend for household total energy consumption in Australia is shown in Figure 1b. It is firmly believed that the $\mathrm{CO}_{2}$ emission will also follow the similar trend [5].

Although several studies by Chen et al. [6] and Zhu et al. [7] have been seen undertaken on sustainable house construction system using various smart materials a huge knowledge gap does exist in our understanding of house ongoing energy performance. This is mainly due to varied climate conditions as heating and cooling energy loads largely depends on ambient conditions especially temperature, humidity and solar radiation. Therefore, the primary objective of this paper is to simulate house energy performance of typical and smart construction for two climatic zones: moderate and arid climate.

In order to reduce energy consumption, the governments of many nations including Australia has initiated various policies, regulations and guidelines can be summarised as follows:
- Implementation of higher building and construction standard and methods.

- Introduction of energy rating systems to estimate home ongoing energy consuming needs and finding alternative ways to reduce the energy consumption.

- Utilisation of various computational tools including widely accepted and reliable energy simulation software to estimate the ongoing heating and cooling need for specific geographical location.

- Exploitation of energy smart construction materials.

- Provide incentives through tax credit and or subsidies for alternative energy use, especially solar and wind energy.

In any new construction systems, methods and materials, it is utmost important to take into account some factors such as a) durability- the material must have high long life resistance to various climate change, hot and cool weather, moisture and drought; b) weight- the material weight should not be heavy and take in to consideration the ease of installation to be safe for occupation; c) costan important factor is being reasonable cost, not too expensive; d) safety- materials should be fire resistant and not flammable. Use of materials that have less hazardous chemicals and can provide better reaction in case of fire will minimise the risk [8-10].

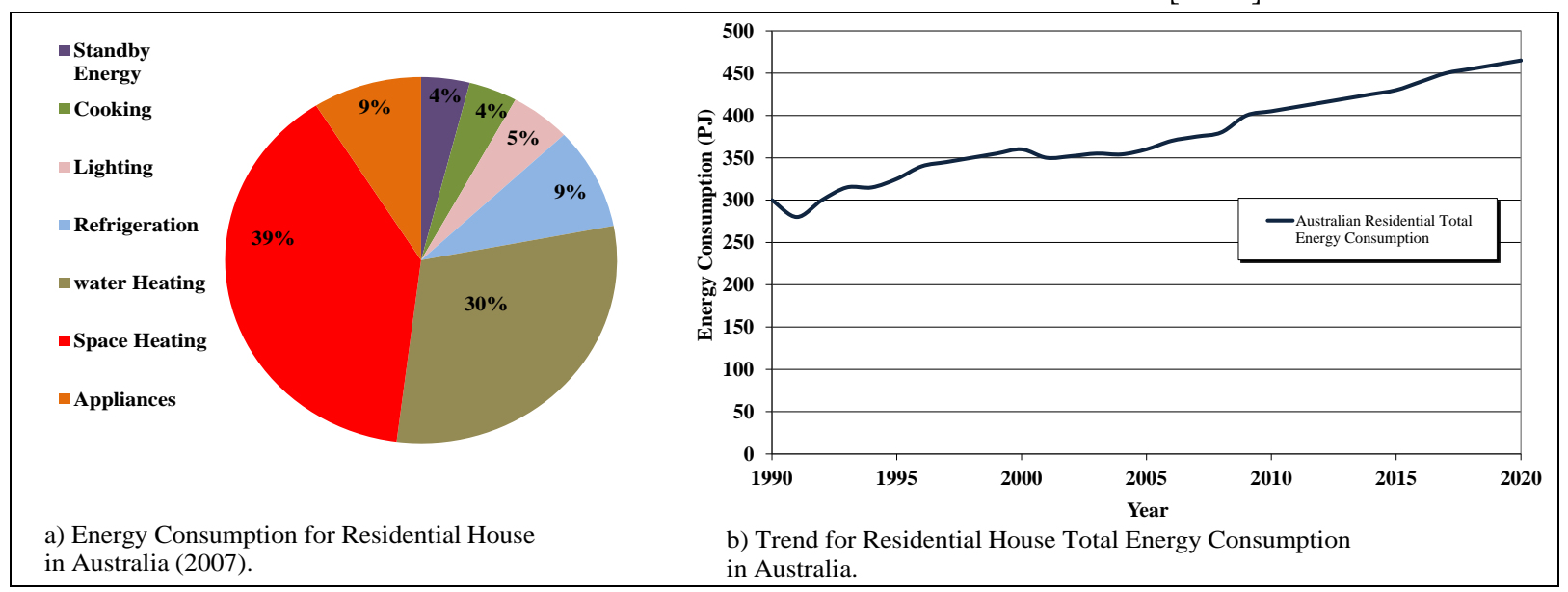

Fig. 1. A continuous increasing trend for the Australian housing sector energy consumption [5] 


\section{DESCRIPTION OF SIMULATED HOUSE ENVELOPES}

The simulated house is a standard 3 bedroom house with an approximate floor area of $161.33 \mathrm{~m}^{2}$ and the total physical volume is around $460 \mathrm{~m}^{3}$. The house consists of a living area, dining area, kitchen, three bedrooms, two bathrooms, an alfresco and a laundry.

The roof slope is around 20 degrees, a widely used roof inclination angle for most houses built in Australia. The roof is made of timber structure with concrete tiles. The foundation (footing) is the standard $\mathrm{H}$ class concrete slabs. The plan view of the simulated house is shown in Figure 2. The windows are standard size with single glass and aluminium frame. A detailed description of the wall systems of the conventional (brick veneer) and new house is given in next sub-sections. The conventional and the new wall systems will be simulated in two climatic zones (Melbourne and Alice Springs). The climate in Melbourne is moderate while the climate in Alice Springs is arid. The arid climate of Alice Springs is closely resembles to some Middle Eastern cities such as Riyadh in Saudi Arabia. Therefore, it is expected that the thermal performance of typical residential house located in Riyadh and Alice Spring will be very close for on going heating and cooling requirement.

\subsection{CONVENTIONAL RESIDENTIAL HOUSE} MATERIALS

A typical conventional Australian residential house envelope generally consists of: a) foundation (concrete slab or timber stamp), roof ceiling and wall systems (brick veneer, timber frame and plasterboard). Further details of the house wall system are described in the next subsection. The roof system consists of flat plasterboard ceiling and inclined roof structures with tiles and/or corrugated iron sheet. A pictorial view of a conventional brick veneer residential house is shown in Figure 3.

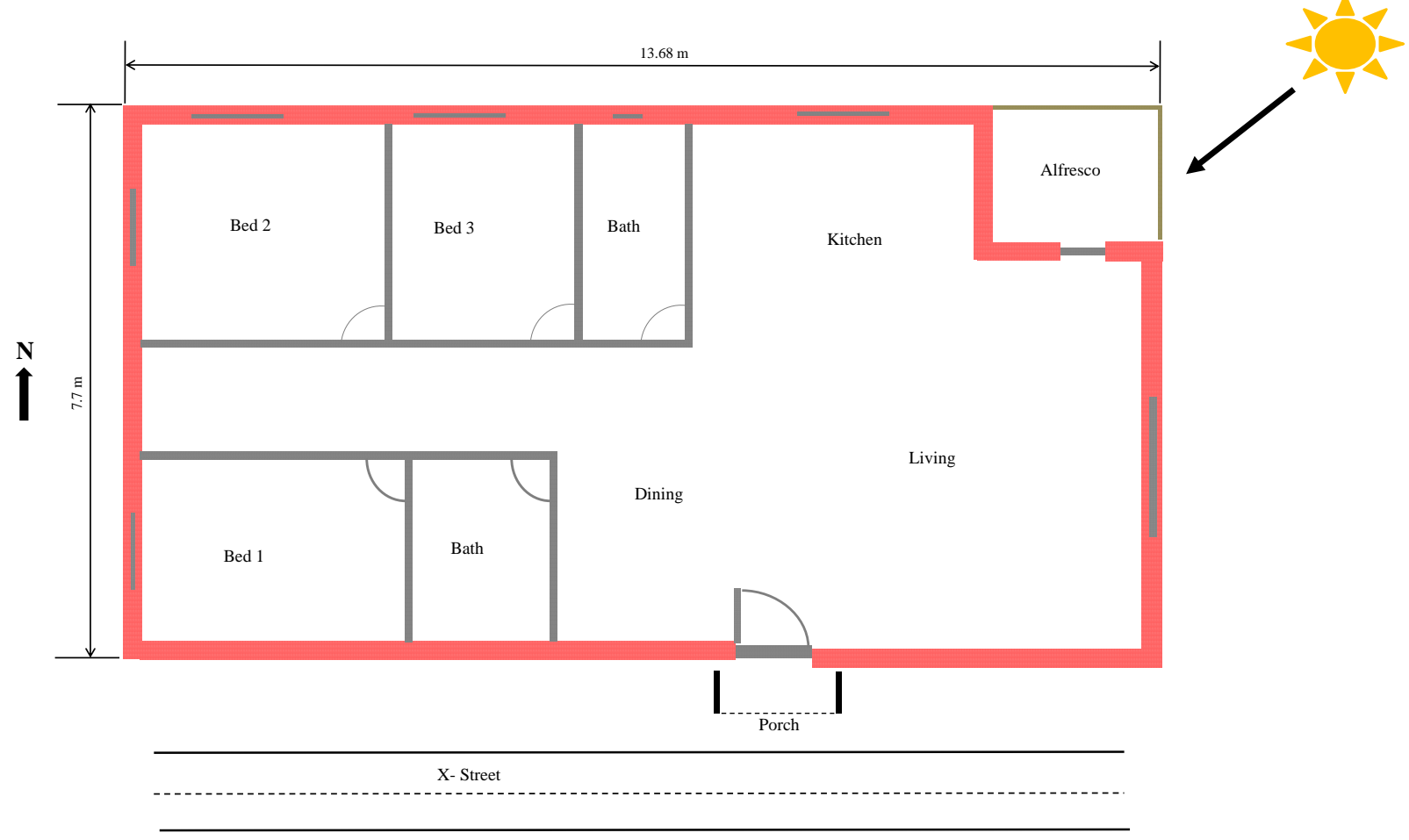

Fig.2. House drawing plan 


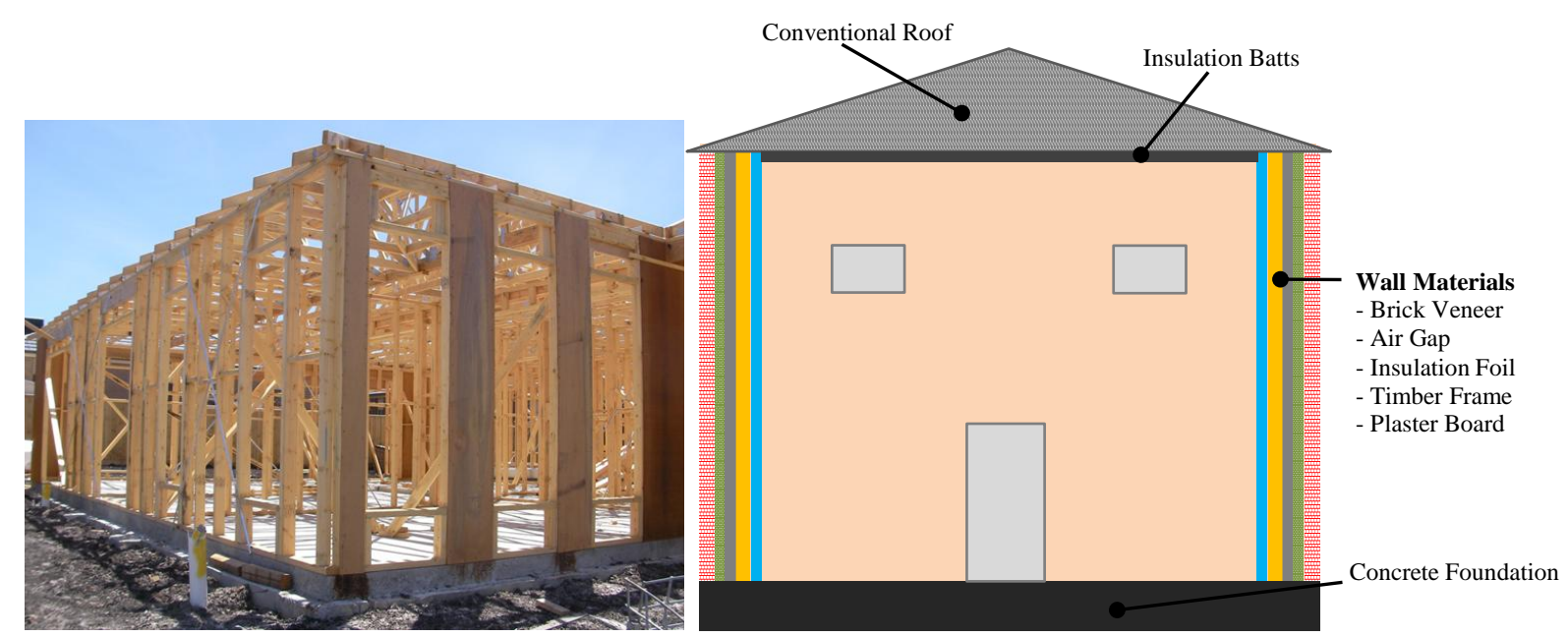

Fig.3. A typical residential house design and materials used [1]

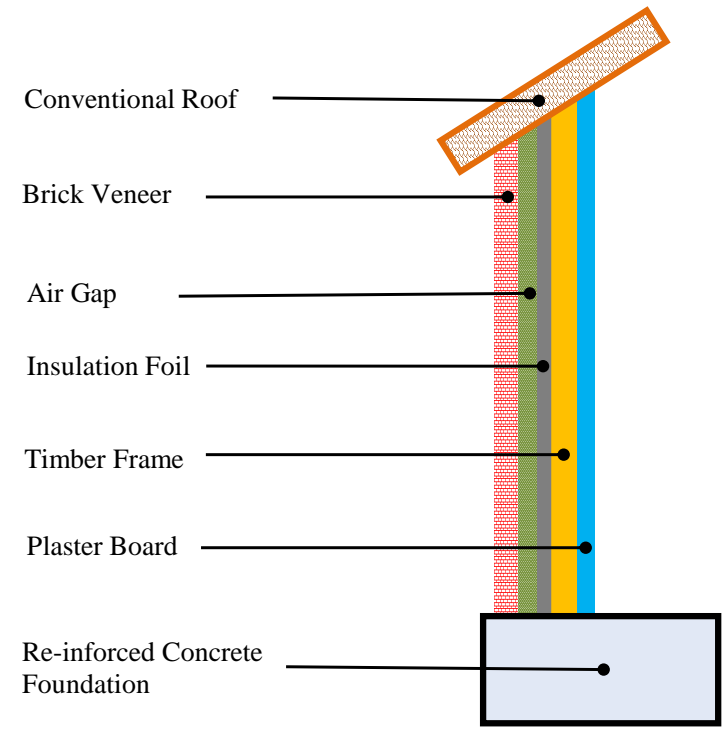

a) Schematic of house wall system

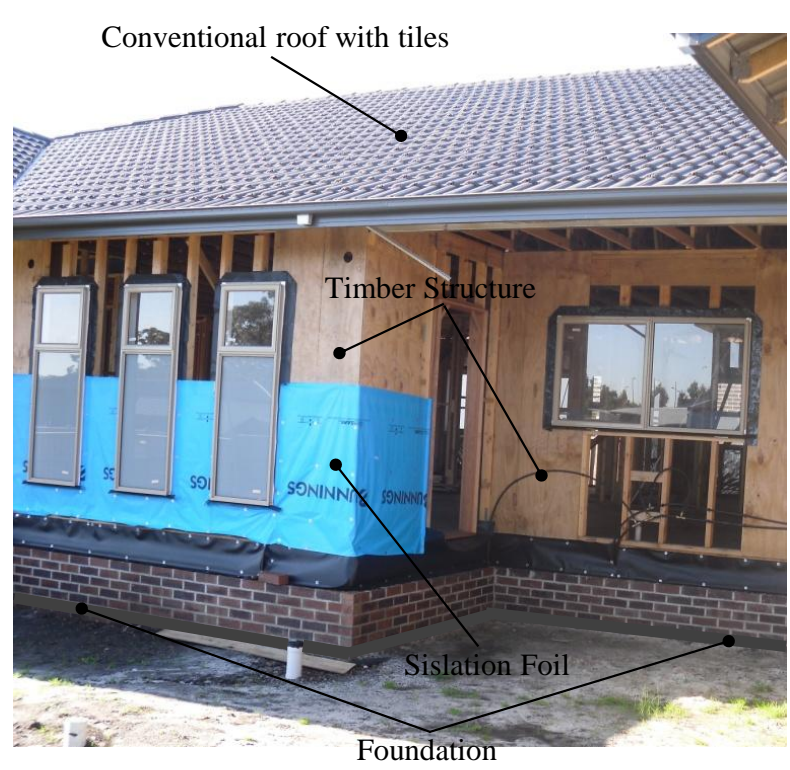

b) Typical house wall system under construction, Australia

Fig.4. Conventional house wall system

\subsection{CONVENTIONAL hOUSE WALL ENVELOPE CONSTRUCTION SYSTEM}

The conventional residential house wall construction in Australia started in early 1950s. The conventional house's external wall generally consists of $110 \mathrm{~mm}$ thick brick veneer, $50 \mathrm{~mm}$ air gap, a thin sisalation foil, approximately $90 \mathrm{~mm}$ timber stud structure filled with insulation batts, and $10 \mathrm{~mm}$ plaster board from inside. The internal wall is generally made of approximately $90 \mathrm{~mm}$ timber stud structure and $10 \mathrm{~mm}$ plasterboard from both sides. The roof structure is made of timber with terracotta/concrete tiles and/or corrugated iron sheet [2]. Figure 4a shows the exterior of a brick veneer house envelope construction system. Figure $4 \mathrm{~b}$ illustrates an example of a typical brick veneer house under construction in outer Melbourne city. 


\subsection{A NEW HOUSE WALL CONSTRUCTION SYSTEM}

A new house wall system selected for this study is made of $10 \mathrm{~mm}$ external cladding (render), $100 \mathrm{~mm}$ reinforced concrete, 50 $\mathrm{mm}$ air gap, $59 \mathrm{~mm}$ polystyrene insulation and $10 \mathrm{~mm}$ plasterboard from inside. The roof structure is kept as conventional without any change as shown in Figure 4. The effects of varied thickness and density of these materials are currently being studied and the findings will be published later. The new house wall system is a close replica for residential houses built in arid climates. Figures $5 \mathrm{a}$ and $5 \mathrm{~b}$ show schematics of a new house wall system and a typical reinforced concrete house wall system (commonly found in the Middle Eastern cities). Table 1 gives a brief wall materials description for conventional and new house wall systems.

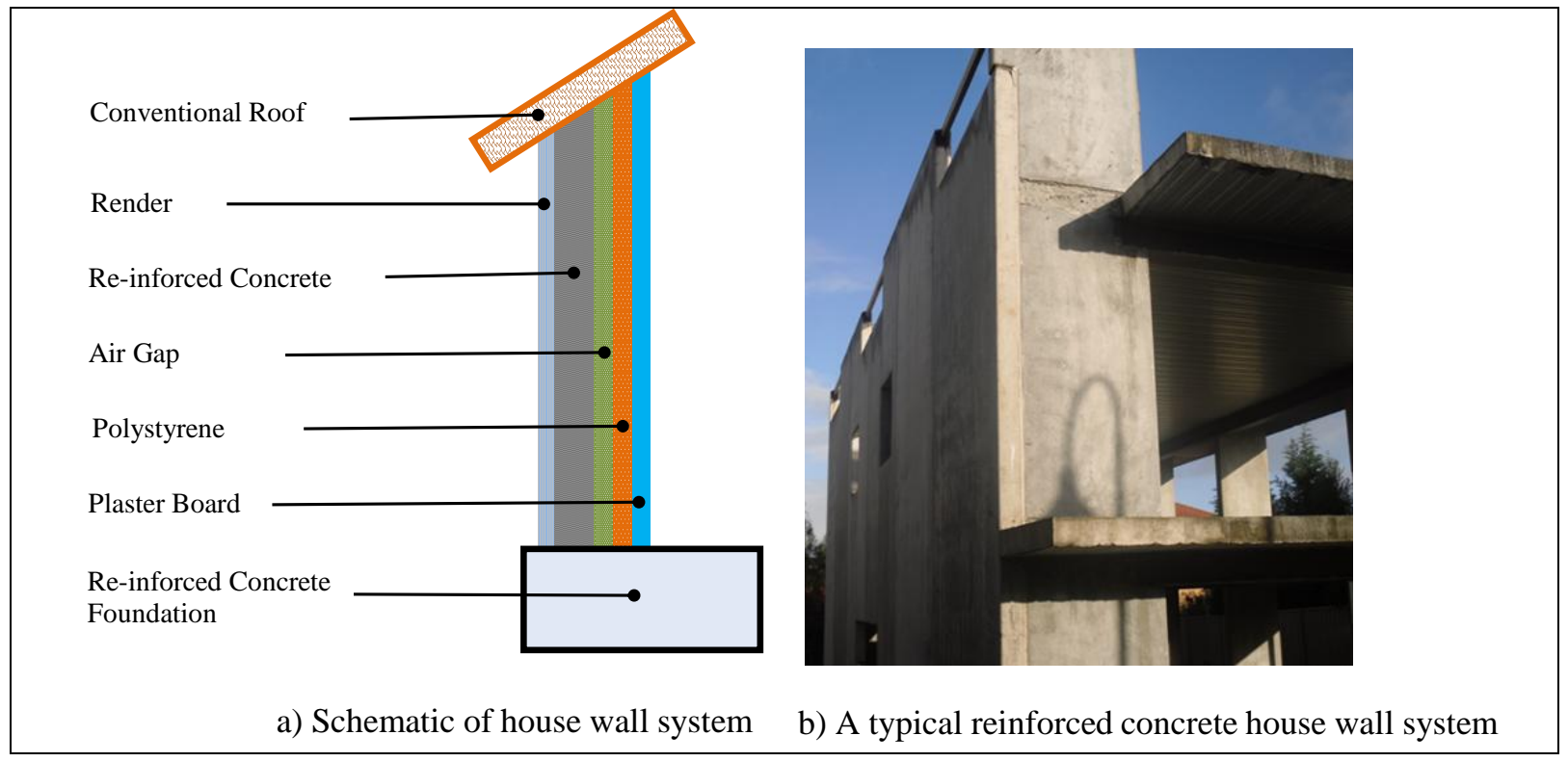

Fig. 5. Alternative house wall and concrete wall construction systems

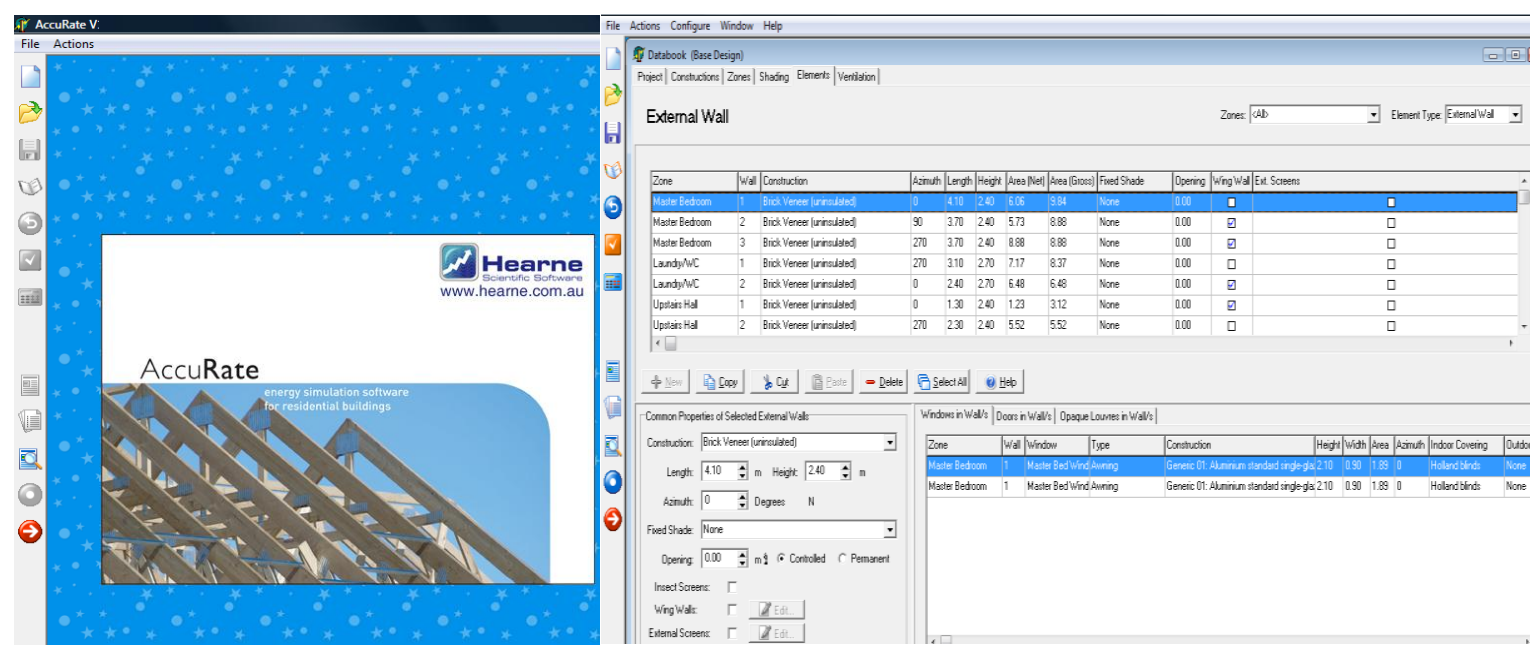

Fig. 6. AccuRate software and house data input screen 
TABLE 1. COMPARISON BETWEEN ALTERNATIVE REINFORCED CONCRETE WALL AND CONVENTIONAL WALL IN REGARDS TO CONSTRUCTION, ENVIRONMENTAL IMPACT AND ENERGY EFFICIENT.

\begin{tabular}{|c|c|c|c|c|}
\hline Items & Conventional house envelope & $\begin{array}{c}\text { Thickness } \\
(\mathrm{mm})\end{array}$ & Alternative house envelope & $\begin{array}{l}\text { Thickness } \\
(\mathrm{mm})\end{array}$ \\
\hline \multirow[t]{5}{*}{ External Wall } & Brick veneer (single) & 110 & Render & 10 \\
\hline & Air cap & 50 & Reinforced concrete panel & 100 \\
\hline & Insulation foil & 50 & Air gap & 50 \\
\hline & Timber structure & 90 & insulation (polystyrene) & 59 \\
\hline & Single glass window + Al. Frame & $3+25$ & Single glass window + Al. frame & $3+25$ \\
\hline Internal Wall & Plaster board & 10 & Plaster board & 10 \\
\hline Ground/Floor & Reinforced concrete slab & 100 & Reinforced concrete slab & 100 \\
\hline \multirow[t]{2}{*}{ Roof } & Timber with concrete tiles $\left(20^{\circ}\right)$ & $20+10$ & Timber with concrete tiles $\left(20^{\circ}\right)$ & $90+20$ \\
\hline & Insulation batts + plaster board & $90+20$ & Insulation batts + plaster board & $20+10$ \\
\hline Internal Door & Timber (mountain ash) & 30 & Timber (mountain ash) & 30 \\
\hline External Door & Timber (hard) & 50 & Timber (hard) & 50 \\
\hline $\begin{array}{l}\text { Environmental } \\
\text { Impact }\end{array}$ & \multicolumn{2}{|c|}{$\begin{array}{l}\text { Higher greenhouse gas emission and carbon } \\
\text { foot print }\end{array}$} & \multicolumn{2}{|c|}{$\begin{array}{l}\text { Less greenhouse gas emission and carbon foot } \\
\text { print }\end{array}$} \\
\hline Energy Efficient & \multicolumn{2}{|c|}{$\begin{array}{l}\text { Less energy efficiency due to high energy } \\
\text { consumption }\end{array}$} & \multicolumn{2}{|c|}{$\begin{array}{l}\text { Higher energy efficiency due to less energy } \\
\text { consumption }\end{array}$} \\
\hline
\end{tabular}

\section{SIMULATION TOOLS AND PROCEDURE}

A large number of house energy simulation software is commercially available world wide. However, all software can not be used for the thermal performance study of residential houses located in varied climate zones due to the unavailability of data for local climate, construction materials, house design and occupant's uses behaviour. For this study, we have selected AccuRate software developed by the Commonwealth Scientific, Industrial and Research Organisation (CSIRO). The software is accredited by all States and Territories in Australia. It possesses a large library of data for 69 climate zones covering all cities and localities of Australia. The software allows incorporating the effects of natural ventilation on energy needs for ongoing heating and cooling. It contains all required heat transfer equations (conduction, convection and radiation). It also provides a star energy rating based on required energy for ongoing heating and cooling at a scale rating of 1 to 10 . The star rating is an indicator of energy efficiency, i.e., higher the star rating is better for the energy saving [11]. A screen shot of AccuRate software's main and data input pages are shown in Figure 6. Further details about the Accurate software, underpinning equations and analytical validation can be found in [12].

In this study, the thermal performance of the external house envelope for both house wall systems (brick veneer and new house) is investigated. The roof structure, window configuration, foundation, door, internal wall, 
etc. were common for both house systems. Thermal characteristics of commonly used building materials are shown in Table 4.

TABLE 4: THERMAL PROPERTIES OF COMMONLY USED BUILDING MATERIALS

\begin{tabular}{|l|c|c|}
\hline Material & $\begin{array}{c}\text { Thermal mass } \\
\text { volumetric heat } \\
\text { capacity } \\
\left(\mathrm{kJ} / \mathrm{m}^{3} . \mathrm{K}\right)\end{array}$ & $\begin{array}{c}\text { Thermal } \\
\text { conductivity } \\
\text { (W/m.K) }\end{array}$ \\
\hline Concrete & 2112 & 0.80 \\
\hline Glass & 2108 & 0.65 \\
\hline Brick veneer & 1484 & 0.80 \\
\hline $\begin{array}{l}\text { Timber } \\
\text { (hard) }\end{array}$ & 1414 & 0.15 \\
\hline Render & 1200 & 0.25 \\
\hline Timber (soft) & 1057 & 0.13 \\
\hline Plasterboard & 924 & 0.25 \\
\hline $\begin{array}{l}\text { Glass fibre } \\
\text { Batt }\end{array}$ & 10.6 & 0.034 \\
\hline Polystyrene & 5.5 & 0.035 \\
\hline
\end{tabular}

The optimal use of solar radiation for house energy needs is generally achieved by orienting the house correctly. Houses built in Southern hemisphere can maximise the gain of solar energy by keeping the living areas to the North in winter. On the other hand, keeping the living areas of the house to the South in the Northern hemisphere the gain of solar energy can be maximised in winter. The solar access can be minimised in summer by using shading device for windows or glass isolation. Hot dry climates with no heating requirements, orientation should aim to exclude sunlight and exposure nature cool air. With good orientation will reduce heating and cooling load, in result, greenhouse emissions reduced. Therefore, in this study, the living areas of both houses are facing the North as they are located in Southern hemisphere. The living areas of the house located in Riyadh should be faced the South as Riyadh is located in Northern hemisphere. The effects of solar radiation on overall heat gain or heat loss have been included in over all heat transfer process.

\subsection{EFFECT OF RELATIVE HUMIDITY}

The indoor thermal comfort of a residential house largely depends on air temperature, relative humidity, radiant temperature and air velocity. According to ANSI/ASHRAE Standard 62-2001, thermal comfort is achieved when over $80 \%$ of all occupants of a house living feel comfortably. For such indoor thermal comfort, the relative humidity should be in the rage of 50 to $70 \%$ [12]. The higher humidity in the house can not only deteriorate the thermal comfort but also increase activities germs, bacteria and viruses. Additionally, the high humidity can reduce the life span of building materials. In order to assess the thermal comfort, it is necessary to study the temperature, velocity and relative humidity of air in the house. In this study, the effect of these parameters on energy was not considered.

\section{RESULTS AND DISCUSSION}

Thermal performances of two house wall systems for two locations have been investigated using energy simulation software 'AccuRate'. Wall materials, their physical dimensions and thermal properties were used in AccuRate simulation software. In addition, the details of windows, doors, floors, ceiling, roof, local latitude, shading schemes and direction of openings (windows, doors) of the house with respect to the flow direction of air were entered into AccuRate software. Figure 7 indicates star energy rating for required heating and cooling energy for a series of regions (cities) all over Australia. The star energy rating includes energy requirement for ongoing heating and cooling only. The energy requirement for other purposes such as water heating and appliances is not included in the 
star energy rating as they depend on house occupant's behaviour [3, 13].

\subsection{Thermal PERFORMANCE OF CONVENTIONAL AND ALTERNATIVE HOUSE WALL SYSTEMS FOR MELBOURNE}

At present, all newly built residential houses in Melbourne must comply with at least 6 stars energy rating. The 6 stars energy rating means the house should not be required more than $114 \mathrm{MJ} / \mathrm{m}^{2}$ per year for Melbourne for on going space heating and cooling. The results obtained for Melbourne by AccuRate simulation are shown in Figure 8. The result indicates that the conventional house wall configuration requires $144.4 \mathrm{MJ} / \mathrm{m}^{2}$ per year for ongoing heating and cooling.

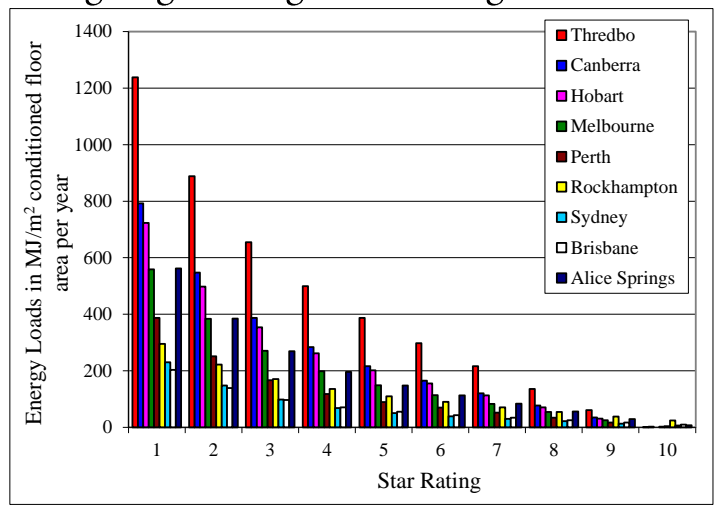

Fig. 7. Standard energy loads against star rating for various cities across Australia [3]

The required energy can be measured at 5.1 stars. On the other hand, the total energy required for the ongoing space heating and cooling of the new house wall is around 127.4 $\mathrm{MJ} / \mathrm{m}^{2}$ per year which equals the energy rating of 5.6 stars. The overall reduction of ongoing heating and cooling is around 12\% compared to the conventional house wall system. The breakdown for the heating cooling energy obtained by computer simulations for both house wall systems in Melbourne is shown in Figure 8.

\subsection{THERMAL PERFORMANCE OF CONVENTIONAL AND ALTERNATIVE HOUSE WALL SYSTEMS FOR ALICE SPRINGS}

The simulated results for both house wall systems located in Alice Springs are shown in Figure 9. The analysed results demonstrate that the conventional house wall system requires around $217 \mathrm{MJ} / \mathrm{m}^{2}$ per year energy for ongoing heating and cooling which equals to the energy star rating of 3.2. However, the total energy required for the heating and cooling of the new house wall system is 156.1 $\mathrm{MJ} / \mathrm{m}^{2}$ per year which is significantly lower compared to the conventional house wall system. The low energy consumption makes the new house's star energy rating to 4.8 stars. The new house wall reduces the energy consumption by almost one third (e.g. 29\%). Figure 9 illustrates the energy requirement separately for heating and cooling for both house wall systems.

\begin{tabular}{|c|c|c|c|c|}
\hline \multicolumn{5}{|c|}{ AREA-ADJUSTED ENERGY REQUIREMENTS } \\
\hline Heating & Cooling (sensible) & Cooling (latent) & Total Energy & Units \\
\hline 107.2 & 35.2 & 2.1 & 144.4 & $\mathrm{MJ} / \mathrm{m}^{2}$.annum \\
\hline
\end{tabular}

a) Star Energy Rating for Conventional House Wall System

\begin{tabular}{|c|c|c|c|c|}
\hline \multicolumn{5}{|c|}{ AREA-ADJUSTED ENERGY REQUIREMENTS } \\
\hline Heating & Cooling (sensible) & Cooling (latent) & Total Energy & Units \\
\hline 92.0 & 24.5 & 10.8 & 127.4 & $\mathrm{MJ} / \mathrm{m}^{2}$.annum \\
\hline
\end{tabular}

b) Star Energy Rating for Alternative House Wall System

Fig.8. Thermal performance for conventional and alternative wall systems of a residential house in Melbourne, Australia 


\subsection{ECONOMIC ANALYSIS FOR CONVENTIONAL AND NEW HOUSE WALL SYSTEMS}

The average construction cost for the conventional and new house wall systems is estimated to be $A \$ 102 / \mathrm{m}^{2}$ and $A \$ 110 / \mathrm{m}^{2}$ respectively. In energy cost estimation, uses of electricity and gas were included. According to the Australian Gas and Electricity Company's retail price, the cost of electricity is around $\$ 0.069 / \mathrm{MJ}$ and the cost of gas is approximately $\$ 0.03 / \mathrm{MJ}$ for the uses in residential buildings. Therefore, the conventional house in Melbourne city requiring heating and cooling energy of 144.4 $\mathrm{MJ} / \mathrm{m}^{2}$ per annum costs approximately $\$ 4.34 / \mathrm{m}^{2}$ per annum for the gas or $\$ 9.97 / \mathrm{m}^{2}$ per annum for the electricity. By contrast, the new house requiring $127.4 \mathrm{MJ} / \mathrm{m}^{2}$ per annum costs $\$ 3.82 / \mathrm{m}^{2}$ per annum for gas or $\$ 8.79 / \mathrm{m}^{2}$ per annum for electricity. The new house wall construction cost is slightly higher than the conventional house by $\$ 8 / \mathrm{m}^{2}$.
However, the costs of energy consumption are lower thus improves the thermal performance. As shown in Table 3, the simple payback period for the new house wall systems is 15.3 years for the use of gas and 6.7 years if electricity is used $[14,15]$. The general features of construction materials used to in this study were according to BCA. The average retail cost for building materials and labour cost as on March 2012 are shown in Table 2.

TABLE 2: COST OF BUILDING MATERIALS IN AUSTRALIA

\begin{tabular}{|l|c|}
\hline Material & Cost $\left(\$ / \mathrm{m}^{2}\right)$ \\
\hline Brick & 49.0 \\
\hline Sisalation foil & 8.0 \\
Timber frame and & 30.0 \\
board & 11.0 \\
\hline Render & 70.0 \\
\hline Reinforced concrete & 15.0 \\
\hline Plaster board & 14.0 \\
Polystyrene & \\
\hline
\end{tabular}

\begin{tabular}{|c|c|c|c|c|}
\hline \multicolumn{5}{|c|}{ AREA-ADJUSTED ENERGY REQUIREMENTS } \\
\hline Heating & Cooling (sensible) & Cooling (latent) & Total Energy & Units \\
\hline 10.8 & 198.6 & 7.7 & 217.1 & $\mathrm{MJ} / \mathrm{m}^{2}$.annum \\
\hline
\end{tabular}

a) Star Energy Rating for Conventional House Wall System

\begin{tabular}{|c|c|c|c|c|}
\hline \multicolumn{5}{|c|}{ AREA-ADJUSTED ENERGY REQUIREMENTS } \\
\hline Heating & Cooling (sensible) & Cooling (latent) & Total Energy & Units \\
\hline 11.7 & 126.4 & 18.0 & 156.1 & $\mathrm{MJ} / \mathrm{m}^{2}$.annum \\
\hline
\end{tabular}

b) Star Energy Rating for Alternative House Wall System

Fig.9. Thermal performance for conventional and alternative wall systems of a residential house in Alice Springs, Australia

TABLE 3. SiMPLE PAYBACK PERIOD

\begin{tabular}{|c|c|c|c|}
\hline Parameter & $\begin{array}{l}\text { Alternative house } \\
\text { wall system }\end{array}$ & $\begin{array}{l}\text { Conventional house } \\
\text { wall system }\end{array}$ & $\begin{array}{l}\text { Saving expenses } \\
\text { Alt. - Conv. }\end{array}$ \\
\hline $\begin{array}{l}\begin{array}{l}\text { Total energy } \\
\left(\mathrm{MJ} / \mathrm{m}^{2} \text {.annum }\right)\end{array} \\
\end{array}$ & 127.4 & 144.4 & 17.0 \\
\hline Construction cost $\left(\$ / \mathrm{m}^{2}\right)$ & 110 & 102 & 8.0 \\
\hline Gas power $(\$ / M J)$ & $127.4 \times 0.03=3.82$ & $144.4 \times 0.03=4.34$ & $3.82-4.34=-0.52$ (gas) \\
\hline Electricity power $(\$ / M J)$ & $127.4 \times 0.069=8.79$ & $144.4 \times 0.069=9.97$ & $8.79-9.97=-1.18$ (electricity) \\
\hline $\begin{array}{l}\text { Simply payback period } \\
\text { (Year) }\end{array}$ & \multicolumn{3}{|c|}{$\begin{array}{l}8.0 / 0.52=15.3 \text { yrs. (gas) } \\
8.0 / 1.18=6.7 \text { yrs. (electricity) }\end{array}$} \\
\hline
\end{tabular}




\section{DISCUSSION AND CONCLUSIONS}

With current building materials and construction methods used in conventional residential houses in Australia, it is extremely difficult to achieve higher energy savings for ongoing heating and cooling. Additionally, the current construction method needs longer time for construction, resulting in higher overall construction cost. Most conventional residential houses lack sufficient thermal mass, insulation and sustainability of design. These result in higher energy needs for ongoing heating and cooling due to the heat loss in winter or heat gain in summer through the house envelope.

The use of smart materials in house wall structures can have notable impact on ongoing energy needs and thermal performance of the house. The new house wall system used in this study showed potential energy savings up to $29 \%$ depending on house locations in arid or moderate climate zones. This energy savings will not only reduce the cost of energy bills but also cut down a significant amount of greenhouse gas emissions. The reduction of energy use will also enhance the conservation finite fossil energy and energy security.

Our preliminary cost estimation indicates that the initial cost of new house wall system is slightly higher compared to the conventional house system. However, the higher initial cost associated with the new house wall system will be paid back in 7 years if electricity is used for ongoing heating and cooling and around 15 years if natural gas is used. This payback period will be much shorter if the consumer price index $(\mathrm{CPI})$ and annual retail price hike are included.

In order to understand and utilise the full potential of new house wall materials and construction methods, a total life cycle analysis (LCA) is required. The LCA will reveal true impact of all new materials on their costs, environment and sustainability. Additionally, studies are also required to have general public feedback and acceptability, and energy uses pattern with and without house occupants for the new house wall system.

The new wall system has better thermal masses and insulations compared to currently used conventional house wall system. The higher thermal mass will allow having better thermal comfort by providing cooler indoor environment during the day in summer and warmer indoor environment in winter at night.

\section{REFERENCES}

[1] Alam, F., Akbarzadeh, A., Dixon, C. and Theos, T., Thermal Performance of Residential House Envelopes, Proceedings of the International Conference on Mechanical, Industrial and Energy Engineering (ICMIEE2010), Paper MIE10-158, ISBN: 978-984-33-2300-2, 23-24 December, Khulna, Bangladesh, 2010.

[2] Alam, F., Khan, M.M.K. and Rasul, M. G., A Comparative Study of Residential Household Energy Consumption in Australia and USA, The International Journal of Mechanical Engineering and Materials Science, Vol 3 (2), p 127-132, 2008.

[3] Alam, F., Rasul, M.G., Saman, W., Theos, T. Khan, M.M.K. and Akbarzadeh, A., Residential House Energy Rating in Australia, Central Region Engineering Conference (CREC), Rockhampton, ISBN 1-921047-62-3, p 1-6, 1415 August, Australia, 2009.

[4] Alam, F, A. A., Rasul, M. G., Khan, M. M. K. and Alam, F., Performance Analysis of a Novel Building Material to Achieve Superior Thermal Comfort and Energy Efficiency in Arid Climate, Proceedings of the International Engineering Conference on Hot Arid Regions (IECHAR 2010), March 1-2, Al-Ahsa, Saudi Arabia, 2010.

[5] Report on Energy Use in the Australian Residential Sector 1986-2020, Department of the 
Environment, Water, Heritage and the Arts, Commonwealth of Australia, 2008, Canberra

[6] Chen, Y., Athienitis, A.K. and Galal, K., Modeling, design and thermal performance of a BIPV/T system thermally coupled with a ventilated concrete slab in a low energy solar house: Part 1, BIPV/T system and house energy concept, Solar Energy, Vol 84, p 1892-1907, 2010.

[7] Zhu, L., Hurt, R., Correia, D. and Boehm, R., Detailed energy saving performance analyses on thermal mass walls demonstrated in a zero energy house, Energy and Buildings, Vol 41, p 303-310, 2010.

[8] Kordjamshidi, M. and King, S., Overcoming problems in house energy ratings in temperate climates: A proposed new rating framework, Energy and Buildings, Vol 41, p 125-132, 2009.

[9] Judkoff, R., Increasing Building Energy Efficiency through Advances in Materials, MRS Bulletin, Vol 33, April, 2008.

[10] Tommerup H, Rose J and Svendsen S., Energyefficient house built according to the energy performance requirements introduced in Denmark in 2006, Energy and Building, Vol 39, p 1123-1130, 2007.

[11] AccuRate Sustainability, Hearne Scientific Software Pty Ltd, technical software for professional, http://www.hearne.com.au/contact, accessed on 16 June, 2011.

[12] Aldawi, F., Moria, H., Alam, F., Date, A. and Akbarzadeh, A., A New House Wall System for Residential Buildings, submitted to Energy and Building, 15 April 20, Elsevier, 2012.

[13] Zmeureanu, R., Fazio, P., DePani, S. and Calla, R., Development of an energy rating system for existing houses, Energy and Buildings, Vol 29, p 107-119, 1999.

[14] Newman, D.G., Eschenbach, T.G., Lavelle, J.P., Engineering Economy Analysis, Oxford University Press, Oxford, 2004.

[15] Tap, M.M, Kamar, H.M., Marsono, A.K., Kamsah, N. and Salimin, K.A.M., Simulation of Thermal Comfort of a Residential House, International Journal of Computer Science Issues, Vol 8, Issue 5, No 2, p 200-2008, ISSN (Online): 1694-0814, 2011. 


\title{
الطاقة الفعالة لنظام الجدران المنزليه للمناطق المناخية الجافة والمعتدلة
}

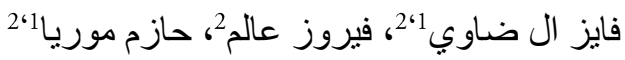 \\ 1 قسم الهندسة الميكانيكية ، كلية ينبع الصناعية، المملكة العربية السعودية

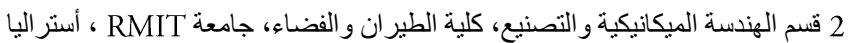

الملخص:

في الوقت الحاضر ، نسبة كبيرة من طاقة الوقود تُشتهلك في المباني السكينة حول العالم و ذللك لأغراض التدفئة و التبريد المستمر. مع نظام التركيب الجداري المستخدم حالياً في المنازل ، من الصعب جداً التوصل الى أعلى معدل كفاءة. لذلك الهدف الأساسي من هذه الدراسة : هو دراسة نظام تركيب جداري جديد و كذلك دراسة اداء الطاقة الحر ارية المستخدمة في التدفئة و التبريد على نوعين من المناخ ( الجاف و المعتدل). أُجريت الدراسة بإستخدام نظام حاسوبي مُحاكي ـ تنشير النتائج الى أنّ نظام التركيب الجداري الجديد المصنوع من مو اد جديدة و أنظمة معيارية يؤدي إلى نوفير ملحوظ بالطاقة مقارنة مع التركيب الجداري الذي يستخدم الطوب العادي و المستخدم بنطاق واسع. تظهر الدراسه الى ان نسبة نوفير الطاقة الذي يستخدم التركيب الجداري الجديد للمناخ

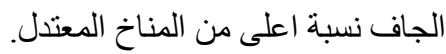

